\title{
RESEARCH ARTICLE \\ The Effects of Garlic Oil and Tartaric Acid on the Quality of Shrimp Stored at $4^{\circ} \mathrm{C}$
}

Wan Norhana Md Noordin ${ }^{1}$, Nannthini Shunmugam², Frederick Adzitey ${ }^{3}$, and Nurul Huda ${ }^{4,5 *}$

\footnotetext{
OPEN ACCESS

${ }^{1}$ Fisheries Research Institute, 11960, Batu Maung, Penang, Malaysia,

${ }^{2}$ School of Industrial Technology, Universiti Sains Malaysia, 11800, USM Penang, Malaysia,

${ }^{3}$ Department of Food Science and Technology, University for Development Studies, Box TL 1882, Tamale, Ghana,

4 Faculty of Food Science and Nutrition, Universiti Malaysia Sabah, 88400, Kota Kinabalu, Sabah, Malaysia,

5 Adjunct Professor, Universitas Sultan Ageng Tirtayasa, 42124, Banten, Indonesia

* Corresponding Author:

drnurulhuda@ums.edu.my

Received: 11 March 2020

Accepted: 14 December 2020

Published: 24 May 2021

-Squalen Bulletin of Marine and Fisheries Postharvest and Biotechnology, 2021. Accreditation Number: 148/M/KPT/2020. ISSN: 2089-5690, e-ISSN: 2406-9272. doi: 10.15578/squalen. 448
}

\begin{abstract}
The objectives of this study were to determine the effects of garlic oil (GO) and tartaric acid (TA) on microbiological, $\mathrm{pH}$, and Thiobarbituric Acid Reactive Substances (TBARS) (lipid peroxidation) of shrimp stored at $4^{\circ} \mathrm{C}$. Shrimp of 2 $\mathrm{kg}$ were dipped in GO and TA solutions at 1:2 shrimp/treatment solutions (w/w) for $30 \mathrm{~min}$ under $25^{\circ} \mathrm{C}$. Sodium metabisulfite (MBS) and sterile distilled water $\left(\mathrm{dH}_{2} 0\right)$ were used as positive and negative controls, respectively. Shrimp were drip-dried for $5 \mathrm{~min}$, packaged, and stored in a chiller $\left(4^{\circ} \mathrm{C}\right)$ for 10 days. The shrimp were analysed on days $0,3,5,7$, and 10. Total aerobic plate count, psychotropic bacteria count, Listeria monocytogenes, Salmonella enterica serovar Typhimurium (S. Typhimurium) and Vibrio parahaemolyticus counts ranged from 3.52-8.73 $\log \mathrm{CFU} / \mathrm{g},<3.30-5.16 \log \mathrm{CFU} / \mathrm{g}, 3.48-7.60 \log \mathrm{CFU} / \mathrm{g}$, 3.42-6.34 $\log \mathrm{CFU} / \mathrm{g}$ and 3.48-5.55 log CFU/g, respectively. The $\mathrm{pH}$ of shrimp ranged from 6.64 to 8.03. The $\mathrm{pH}$ of shrimp dipped in MBS (7.70) and TA+GO (7.70) was lowest at the end of storage period. TBARS values ranged from 0.70 2.66 and TBARS values for shrimp treated with MBS (1.83) were lowest at day 10. In general, microbiological counts, $\mathrm{pH}$ and TBARS values of sample treated with $\mathrm{TA}+\mathrm{GO}$ increased with storage time, however comparable to MBS. Treatment of shrimp with GO and TA could inhibit the growth of foodborne pathogens. The $\mathrm{pH}$ of the test and control shrimp were similar on day 10. Lipid peroxidation was lowest for TA and MBS treated shrimp by day 10 .
\end{abstract}

Keywords: shrimp quality, microbial safety, garlic oil, tartaric acid, storage study

\section{Introduction}

Shrimp are the most economically important, internationally traded seafood commodity in the world (FAO, 2016). Fresh shrimp presents a favourable environment for microbial growth and microbiological spoilage is one of the main causes of limited shelf-life and safety, particularly if the shrimp are contaminated with pathogens. Spoilage and presence of pathogens, such as Listeria monocytogenes and Salmonella, are among the most common reasons for shrimp product detentions and recalls (USFDA, 2008; Consumer Reports, 2015). These are the concerns of the importing countries because illnesses including listeriosis and salmonellosis have been related to shrimp (NACMCF, 2008). For these reasons, there is an avid interest in decreasing the surface microbial loads of shrimp, particularly the pathogens.

Contamination of seafood can occur before harvest or at any point from harvest through final preparation. However, the survival of pathogens is more likely to occur in foods that are consumed undercooked or raw
(Amagliani, Brandi \& Schiavano, 2012). The major sources responsible for the occurrence of Salmonella in aquaculture shrimp are poor sanitation, crosscontamination during handling and inappropriate disposal of human and animal wastes (NACMCF, 2008; Amagliani et al., 2012). The primary source of $L$. monocytogenes associated with shrimp is surface contamination during handling and processing. $V$. parahaemolyticus on the other hand, is widespread in the marine and estuarine environments and is frequently isolated from seafood (particularly shellfish and shrimp). The infections of $V$. parahaemolyticus are caused by improper refrigeration, insufficient cooking and crosscontamination (NACMCF, 2008; Zarei, Borujeni, Jamnejad, \& Khezrzadeh, 2012). Consumers demand safe food which should be produced by using safe intervention strategies. Potentially harmful additives, namely sulfiting agents, are used in shrimp preservation to generate allergic reactions (Over, Hettiarachchy, Johnson, \& Davis, 2009; Nirmal \& Benjakul, 2012). For these reasons, studies on the effectiveness of natural antimicrobials, generally regarded as safe 
(GRAS) substances against foodborne pathogens have been and continue to be conducted (Wan Norhana, Poole, Deeth, \& Dykes, 2010; Salem \& Amin, 2012; Bahurmiz, Ahmad, Ismail, Adzitey, \& Sulaiman, 2016; Wan Norhana, Nannthini, Huda, \& Adzitey, 2018).

This study was carried out to determine the effects of tartaric acid, and garlic oil (alone and in combination) on the total aerobic plate counts, psychotropic bacteria counts, L. monocytogenes, $S$. Typhimurium and $V$. parahaemolytics counts, chemical and sensory qualities of shrimp. Food grade tartaric acid is a GRAS substance with colorless, odorless and slight acidic taste, while garlic on the other hand is common condiment used in shrimp based dishes. Garlic has been proven to posses antimicrobial activity as well as anti-oxidant property. Uses of natural anti-oxidants, especially essential oils, could be a potential means to retard lipid oxidation and rancidity of shrimp oil during extended storage (Takeungwongtrakul \& Benjakul, 2014). Our earlier study indicated that tartaric acid was effective in reducing total aerobic plate count and did not cause significant changes in $\mathrm{pH}$, colour and hardness of shrimp (Wan Norhana et al., 2018). Furthermore, tartaric acid treated shrimp showed comparable results with sodium metabisulfite, the traditional preservative for shrimp to reduce the microbial loads in shrimp.

\section{Material and Methods}

\section{Shrimp Sample Preparations}

Commercial size fresh shrimp (Penaeus monodon) (about 90-100 days of culture) were obtained from a shrimp farm in Balik Pulau, Pulau Pinang, Malaysia. The shrimp were immediately transported on ice and thoroughly washed with sterile distilled water upon reaching the laboratory. At the laboratory, the shrimp were rinsed with sterile distilled water (SDW) and weighed. The mean weight of the shrimp obtained from the ponds was around $18.4 \mathrm{~g}$. Large size shrimp $(>19.0 \mathrm{~g})$ and small size shrimp $(<17.0 \mathrm{~g})$ were not used in the study in order to minimise the effects of size on the results. They were then divided into 4 groups of $2.0 \mathrm{~kg}$ each. The first three groups were inoculated with L. monocytogenes, S. Typhimurium and $V$. parahaemolytics, respectively. The fourth group served as the control.

\section{Preparation and I noculation of Shrimp with Pathogens}

Food isolates of L. monocytogenes Scott A (Food Science Australia, Brisbane, Australia), Salmonella enterica subsp. enterica serovar $S$. Typhimurium (National Public Health Laboratory, Malaysia), and $V$. parahaemolyticus (National Fish Health, Fisheries Department, Malaysia) were used. The bacterial cultures were obtained from the respective labs in an agar slant since 2015. Since then, the Bacteriology Lab of the Fisheries Research Institute, Batu Maung has maintained the bacterial stock according to standard protocols. Working cultures for each species was cultured in $3 \mathrm{~mL}$ Tryptic Soy Agar (TSA) (Oxoid, Basingstoke, UK) and incubated at $37{ }^{\circ} \mathrm{C}$ for $18 \mathrm{~h}$. Two percent $\mathrm{NaCl}$ was added to all the media used for $V$. parahaemolyticus. Cells were harvested by centrifugation at $9,000 \times \mathrm{g}$ for $10 \mathrm{~min}$ at $4{ }^{\circ} \mathrm{C}$. The supernatant was decanted and the pellet suspended in sterile $0.85 \%$ saline solution and then further diluted to obtain a working culture of approximately $6 \log \mathrm{CFU} /$ $\mathrm{mL}$. Inoculation of shrimp with the bacteria was carried out as described by Wan Norhana et al. (2010).

\section{Treatment of Shrimp with Garlic Oil and Tartaric Acid}

Food grade tartaric acid (99.7\%; FCC; FDA 21 CFR 163.110; EU Regulation 1334/2008) and garlic oil (Allium sativum; FDA 21 CFR 184.1317; EU Reg. 1334/2008) were purchased from SAFC, Milwaukee, USA. Inoculated and non-inoculated shrimp were dipped in $5.0 \mathrm{~g} / \mathrm{L}$ tartaric acid (TA), $25 \mathrm{~mL} / \mathrm{L}$ garlic oil (GO), a mixture containing $5.0 \mathrm{~g} / \mathrm{L}$ tartaric acid and 25 $\mathrm{mL} / \mathrm{L}$ garlic oil $(\mathrm{TA}+\mathrm{GO}), 1.25 \%$ sodium metabisulfite (MBS) as the positive control and sterile distilled water $\left(\mathrm{dH}_{2} \mathrm{O}\right)$ as the negative control. The ratio of dipping was 1:2 (shrimp: dipping solution). The shrimp were dipped in the treatment and control solutions for 30 min at $25^{\circ} \mathrm{C}$ and agitated from time to time to ensure even distribution of the antimicrobial solutions. After which the shrimp were drip-dried for $5 \mathrm{~min}$, packed in labelled polyethylene containers and stored in a chiller $\left(4^{\circ} \mathrm{C}\right)$ for 10 days. Microbiological, $\mathrm{pH}$, and TBARS analyses were performed on days $0,3,7$, and 10 .

\section{Microbiological Analysis}

Microbiological analysis was carried out for total aerobic plate count, psychrotrophic count, $L$. monocytogenes, $S$. Typhimurium and $V$. parahaemolyticus. A $25 \mathrm{~g}$ shrimp of both inoculated and non-inoculated were added to $225 \mathrm{~mL}$ of sterile $0.85 \%$ saline and homogenised. Serial dilutions were prepared by diluting $1 \mathrm{~mL}$ of suspension in $9 \mathrm{~mL}$ of $0.85 \%$ saline. A volume of $0.1 \mathrm{~mL}$ of appropriate dilutions was spread-plated on appropriate selective media Polymyxin Acriflavin Lithium-chloride Ceftazidime Esculin Mannitol (PALCAM), Xylose Lysine Deoxycholate (XLD), Thiocitrate Bile Salt Agar (TCBS) and non-selective media Plate Count Agar (PCA) (Wan Norhana, Poole, Deeth, \& Dykes, 2012). 
Specifically, dilutions from the L. monocytogenes inoculated samples were plated on a PALCAM agar and incubated at $37^{\circ} \mathrm{C}$ for $48 \mathrm{~h}$. Dilutions from the $S$. Typhimurium inoculated samples were plated on XLD agar and incubated at $37^{\circ} \mathrm{C}$ for $24 \mathrm{~h}$ and dilutions from the $V$. parahemolyticus inoculated samples were plated on TCBS agar and incubated at $35^{\circ} \mathrm{C}$. A few selected colonies from countable PALCAM, XLD and TCBS agar plates were streaked onto TSA for purity and confirmation tests including: Gram stain, oxidase test, umbrella motility in Sulfide Indole Medium, carbohydrate fermentation pattern and hydrogen sulphide production in Triple Sugar Iron (TSI) agar and salt tolerance test for $V$. parahemolyticus were carried out. For the uninoculated shrimp, the following groups of native microflora were enumerated; total aerobic bacteria on PCA after incubation at $30^{\circ} \mathrm{C}$ for 2 days and psychrotrophic bacteria on PCA incubated at $4^{\circ} \mathrm{C}$ for 5-7 days. All plates were examined visually for typical colony types and morphology characteristics associated with each growth medium. Two replicates of at least two appropriate dilutions were enumerated (Wan Norhana et al., 2012).

\section{pH Measurement}

About $25 \mathrm{~g}$ of shrimp were homogenised (from 56 shrimp), using a mechanical homogeniser in $225 \mathrm{~mL}$ of sterile distilled water (Imran, Chawalit, \& Somrote, 2013). The $\mathrm{pH}$ was determined at $25^{\circ} \mathrm{C}$ using $\mathrm{pH}$ meter (Ohaus, starter 3100, New Jersey, USA). The $\mathrm{pH}$ was calibrated using both $\mathrm{pH} 4$ and 7 buffers prior to use.

\section{Determination of Thiobarbituric Acid Reactive Substances (TBARS)}

Thiobarturic acid (TBA) solution was prepared by mixing $0.375 \mathrm{~g}$ of TBA (Sigma Aldrich, USA), with 15 $\mathrm{g}$ of trichloroacetic acid (TCA) (Sigma Aldrich, USA) and $0.875 \mathrm{~mL}$ of hydrochloric acid/ $(\mathrm{HCl})$ (Sigma Aldrich, USA) in $100 \mathrm{~mL}$ of distilled water (Thepnuan, Benjakul, \& Visessanguan, 2008). Malondialdehyde (MDA) standard was prepared according to the method described by Karatas, Karatape, and Baysar (2002). A $10 \mu \mathrm{L}$ of 1,1,3,3-tetraethoxypropane (Sigma - Aldrich, USA) was diluted in $10 \mathrm{~mL}$ of $0.1 \mathrm{M} \mathrm{HCl}$ in a screwcapped test tube, placed in a boiling water bath for 5 min and rapidly cooled under running tap water. A working stock solution was prepared by pipetting 1 $\mathrm{mL}$ of the resulting solution (hydrolysed acetal) into a $100 \mathrm{~mL}$ volumetric flask and diluted to volume with distilled water. The stock solution contained $2.92 \mu \mathrm{g} /$ $\mathrm{mL}$ MDA. The stock solution was used for measuring absorbance at $532 \mathrm{~nm}$ using UV- 106A spectrophotometer (Shimadzu, Kyoto, Japan). A standard curve was obtained by plotting absorbance versus concentration of MDA. TBARS were determined according to the method described by Thepnuan et al. (2008). The MDA concentration was calculated from the regression equation derived from the standard curve, and TBARS values expressed using the equation below:

TBARS $(\mathrm{mg}$ MDA $/ \mathrm{kg}$ sample $)=\frac{(\text { MDA }(\mathrm{mg} \mathrm{MDA} / \mathrm{mL}) \times 10 \mathrm{~mL})}{(0.002 \mathrm{~kg} \mathrm{sample})}$

\section{Statistical Analysis}

Three experimental replicates were conducted. Microbial counts were transformed into log values. All data were subjected to a two-way analysis of variance (ANOVA) and Tukey's test for comparison of means using SPSS version 20.0 for Windows (SPSS Inc., Chicago, IL, USA). Significance was defined at a level of $p<0.05$.

\section{Results and Discussion}

\section{Total Plate Count and Psychotropic Bacteria Count}

Table 1 shows the changes in total aerobic plate count (TPC) and psychotropic bacteria count (PBC) of shrimp dipped in garlic oil and tartaric acid during storage at $4{ }^{\circ} \mathrm{C}$ for 10 days. Initial TPC of shrimp prior to treatment ranged from $4.77-5.44 \mathrm{log} \mathrm{CFU} / \mathrm{g}$. Dipping in TA and TA+GO reduced $(p<0.05)$ the TPC by 1.7 and $1.47 \log$, respectively. During storage period, TPC of shrimp continued to increase and was highest $(p<0.05)$ in shrimp dipped in $\mathrm{dH}_{2} \mathrm{O}$. At the end of storage period (day 10), shrimp treated with MBS had the lowest TPC (5.31 log CFU/g), followed by shrimp dipped in TA and TA+GO with TPC of 5.85 and $6.09 \log \mathrm{CFU} / \mathrm{g}$, respectively. TPC of 7.0 to 8.0 $\log \mathrm{CFU} / \mathrm{g}$ is generally defined as the onset of spoilage for fresh shrimp and The International Commission on Microbiological Specifications for Foods (ICMSF) specified a maximum TPC of $7 \mathrm{log} \mathrm{CFU} / \mathrm{g}$ for frozen shrimp (ICMSF, 1986). In the present study, TPC for the shrimp samples treated with $\mathrm{dH}_{2} \mathrm{O}$ and $\mathrm{GO}$ exceeded the permitted level on day 7 and 10, respectively. Maneesin, Chinnasri, Vongsawasdi, \& Wangchanachai (2013) observed that TPC of shrimp treated with $\mathrm{dH}_{2} \mathrm{O}$ and $1.5 \mathrm{~mL} / \mathrm{L}$ garlic oil exceeded the recommended limit on day 6 and 11, respectively. Although TPC of MBS treated shrimp were the lowest on day 10 , the count was not significantly $(p>0.05)$ different from TA and TA+GO. Hence, all the three treatments resulted in a 3-day extension of shrimp microbial shelf life compared to the control $\left(\mathrm{dH}_{2} \mathrm{O}\right)$.

The initial psychotropic bacteria counts (PBC) were $<3.30 \log \mathrm{CFU} / \mathrm{g}$ and the counts did not change much in shrimp subjected to the various treatments. The 
Table 1. Total aerobic plate counts and psychotropic bacteria counts of non-inoculated shrimps dipped in tartaric acid (TA), garlic oil (GO), and mixture of TA and GO stored at $4{ }^{\circ} \mathrm{C}$ for 10 days

\begin{tabular}{|c|c|c|c|c|c|c|}
\hline \multirow{2}{*}{$\begin{array}{l}\text { Bacterial } \\
\text { Count }\end{array}$} & & \multirow[b]{2}{*}{ Initial } & \multicolumn{4}{|c|}{ Storage period (days) } \\
\hline & & & 0 & 3 & 7 & 10 \\
\hline \multirow{5}{*}{$\begin{array}{l}\text { Total plate } \\
\text { counts } \\
(\log \text { CFU/g) }\end{array}$} & TA & $5.44 \pm 0.65 \mathrm{Ba}$ & $3.74 \pm 0.28 \mathrm{Aab}$ & $5.15 \pm 0.65 \mathrm{Bab}$ & $5.60 \pm 0.26 \mathrm{Ba}$ & $5.85 \pm 0.42 \mathrm{Bab}$ \\
\hline & $\mathrm{TA}+\mathrm{GO}$ & $4.99 \pm 0.32 \mathrm{Ba}$ & $3.52 \pm 0.08 \mathrm{Aa}$ & $4.67 \pm 0.39 \mathrm{Aba}$ & $5.86 \pm 0.76 \mathrm{Bab}$ & $6.09 \pm 0.68 \mathrm{Bab}$ \\
\hline & GO & $5.04 \pm 0.57 \mathrm{ABa}$ & $4.12 \pm 0.29 \mathrm{Ab}$ & $5.54 \pm 0.49 \mathrm{Bab}$ & $6.08 \pm 0.85 \mathrm{BCab}$ & $7.03 \pm 0.28 \mathrm{Cb}$ \\
\hline & MBS & $4.77 \pm 1.01 \mathrm{ABa}$ & $3.89 \pm 0.21 \mathrm{Aab}$ & $5.20 \pm 0.54 \mathrm{Bab}$ & $5.37 \pm 0.34 \mathrm{Ba}$ & $5.31 \pm 0.16 \mathrm{Ba}$ \\
\hline & $\mathrm{dH}_{2} \mathrm{O}$ & $4.91 \pm 0.07 \mathrm{Aa}$ & $4.33 \pm 0.19 \mathrm{Ac}$ & $6.41 \pm 0.31 \mathrm{Bb}$ & $7.17 \pm 0.38 \mathrm{Bb}$ & $8.73 \pm 0.40 \mathrm{Cc}$ \\
\hline \multirow{5}{*}{$\begin{array}{l}\text { Psy chotropic } \\
\text { bacteria } \\
(\log C F U / g)\end{array}$} & TA & $<3.30 \mathrm{Aa}$ & $<3.30 \mathrm{Aa}$ & $3.66 \pm 0.33 \mathrm{Aa}$ & $4.38 \pm 0.17 \mathrm{Ba}$ & $5.11 \pm 0.12 \mathrm{Ca}$ \\
\hline & $\mathrm{TA}+\mathrm{GO}$ & $<3.30 \mathrm{Aa}$ & $<3.30 \mathrm{Aa}$ & $<3.30 \mathrm{Aa}$ & $4.29 \pm 0.37 \mathrm{Ba}$ & $5.16 \pm 0.17 \mathrm{Ca}$ \\
\hline & GO & $<3.30 \mathrm{Aa}$ & $<3.30 \mathrm{Aa}$ & $3.81 \pm 0.08 \mathrm{Aa}$ & $4.77 \pm 0.44 \mathrm{Bab}$ & $5.13 \pm 0.06 \mathrm{Ca}$ \\
\hline & MBS & $<3.30 \mathrm{Aa}$ & $<3.30 \mathrm{Aa}$ & $3.55 \pm 0.36 \mathrm{Aba}$ & $4.48 \pm 0.26 \mathrm{BCa}$ & $5.13 \pm 0.44 \mathrm{Ba}$ \\
\hline & $\mathrm{dH}_{2} \mathrm{O}$ & $<3.30 \mathrm{Aa}$ & $<3.30 \mathrm{Aa}$ & $4.82 \pm 0.16 \mathrm{Bb}$ & $5.50 \pm 0.36 \mathrm{Cb}$ & $6.61 \pm 0.20 \mathrm{Db}$ \\
\hline
\end{tabular}

Note: Values were reported as means \pm S.D. of triplicate groups

Mean values in the same treatment/row with different uppercase were significantly different $(p<0.05)$

Mean values in the same day/column with different lowercase were significantly different $(p<0.05)$.

TA ; tartaric acid; TA+GO : tartaric acid + garlic oil; GO : garlic oil; MBS ; sodium metabisulfite

psychotropic counts continued to increase during the storage period. At the end of storage period, $\mathrm{PBC}$ of shrimp dipped in MBS, TA, GO and TA+GO were significantly lower $(p<0.05)$ than shrimp dipped in $\mathrm{dH}_{2} \mathrm{O}$. The psychotropic counts increased $(p<0.05)$ in shrimp dipped in $\mathrm{dH}_{2} \mathrm{O}$ but were still of acceptable quality up to end of storage period (day 10). The Gramnegative psychotropic bacteria are the major group of microorganisms responsible for spoilage of iced stored fish and shellfish (Gram \& Huss, 1996). Wan Norhana et al. (2012) reported similar PBC for Penaeus monodon treated with organic acids such as potassium sorbate (4.77 log CFU/g), sodium benzoate (4.29 log $\mathrm{CFU} / \mathrm{g}$ ) and sodium diacetate (4.73 log CFU/g) on day 7 of storage at $4{ }^{\circ} \mathrm{C}$. PBC of shrimp dipped in a mixture of $\mathrm{TA}+\mathrm{GO}$ treated shrimp remained below $3.3 \log \mathrm{CFU} /$ $\mathrm{g}$ on day 0 and day 3 of storage and was $5.16 \mathrm{log}$ $\mathrm{CFU} / \mathrm{g}$ on day 10 . Similar counts were observed by Nirmal \& Benjakul (2012) in white shrimp dipped in green tea and ascorbic acid mixture stored at $4{ }^{\circ} \mathrm{C}$.

\section{L. monocytogenes, V. parahaemolyticus and S. Typhimurium Counts}

Colonies with small grey colonies $(1 \mathrm{~mm})$ with a black halo on PALCAM agar were counted as $L$. monocytogenes. Generally, L. monocytogenes increased $(p<0.05)$ during the storage period. L. monocytogenes counts of shrimp dipped in TA, GO, and TA+GO solutions decreased $(p<0.05)$ on day 0 (Table 2$)$. Mixture of TA+GO was as effective as MBS, as highest reduction of $1.25 \mathrm{log} \mathrm{CFU} / \mathrm{g}$ was observed. Interestingly, on day 10, Listeria counts in shrimp treated with all treatments were significantly $(p<0.05)$ lower than L. monocytogenes counts in shrimp dipped in $\mathrm{dH}_{2} \mathrm{O}$, that indicate $\mathrm{TA}, \mathrm{GO}, \mathrm{TA}+\mathrm{GO}$ treatments are effective in reducing the number of $L$. monocytogens in shrimp.

Wan Norhana, Azman, Poole, Deeth, \& Dykes (2009) made a similar observation in L. monocytogenes counts in shrimp treated with Averrhoa bilimbi (bilimbi extract) and tamarind extracts stored at $4{ }^{\circ} \mathrm{C}$ and attributed it to the psychotropic nature of the pathogen. No significant ( $p>0.05)$ effect was observed for $L$. monocytogenes counts in shrimp treated with TA or a mixture of TA+GO compared to shrimp dipped in the MBS solution. Rohani, Moradi, Mehdizadeh, SaeiDehkordi, \& Griffiths (2011) observed that garlic oil combined with nisin had a significant anti-listerial activity compared to garlic oil alone, which was also the case in this study.

Red colonies with black centres on XLD agar were identified as $S$. Typhimurium. $S$. Typhimurium counts in shrimp dipped in $\mathrm{dH}_{2} \mathrm{O}$ was $5.17 \log \mathrm{CFU} / \mathrm{g}$ (Table 2). $S$. Typhimurium counts in shrimp dipped in TA+GO and TA decreased $(p<0.05)$ on day 0 compared to $S$. Typhimurium counts shrimp dipped in $\mathrm{dH}_{2} \mathrm{O}$. On day $0, S$. Typhimurium counts in shrimp treated with different treatment decreased, but as storage progressed, the counts increased $(p<0.05)$. On day 10 , the counts of shrimp dipped in $\mathrm{dH}_{2} \mathrm{O}$ were much higher compared to other treatments. TA and TA+GO were more effective in reducing $(p>0.05) S$. Typhimurium counts (by 1.76 and $1.6 \mathrm{log} \mathrm{CFU} / \mathrm{g}$, respectively) compared to MBS. Over et al. (2009) also observed lower $S$. Typhimurium counts in chicken meat treated with tartaric acid $(75 \mathrm{mM}$ and $150 \mathrm{mM})$ stored at $4{ }^{\circ} \mathrm{C}$. $S$. Typhimurium counts decreased on day 3 for all treated shrimp samples except those dipped 
Table 2. L. monocytogenes, S. Typhimurium and V. parahaemolyticus counts of shrimps dipped in tartaric acid (TA), garlic oil (GO), and mixture of TA and GO stored at $4{ }^{\circ} \mathrm{C}$ for 10 days

\begin{tabular}{llllll}
\hline Test bacteria & & \multicolumn{4}{c}{ Storage period (days) } \\
\cline { 2 - 5 } L. monocytogenes & TA & $3.48 \pm 0.01^{\mathrm{a}} \mathrm{Aa}$ & $3.91 \pm 0.25^{\mathrm{a}} \mathrm{Aa}$ & $5.16 \pm 0.56^{\mathrm{b}} \mathrm{Bab}$ & $5.32 \pm 0.17^{\mathrm{b}} \mathrm{Ba}$ \\
(log CFU/g) & $\mathrm{TA}+\mathrm{GO}$ & $3.48 \pm 0.00^{\mathrm{a}} \mathrm{Aa}$ & $3.73 \pm 0.18^{\mathrm{b}} \mathrm{Aa}$ & $5.06 \pm 0.48^{\mathrm{b}} \mathrm{Bab}$ & $5.30 \pm 0.21^{\mathrm{b}} \mathrm{Ba}$ \\
& $\mathrm{GO}$ & $3.51 \pm 0.04^{\mathrm{a}} \mathrm{Aa}$ & $4.02 \pm 0.24^{\mathrm{b}} \mathrm{Aa}$ & $5.58 \pm 0.66^{\mathrm{b}} \mathrm{Bab}$ & $5.81 \pm 0.41^{\mathrm{b}} \mathrm{Ba}$ \\
& $\mathrm{MBS}$ & $3.48 \pm 0.00^{\mathrm{a}} \mathrm{Aa}$ & $3.53 \pm 0.08^{\mathrm{a}} \mathrm{Aa}$ & $4.37 \pm 0.94^{\mathrm{a}} \mathrm{ABa}$ & $5.04 \pm 0.11^{\mathrm{b}} \mathrm{Ba}$ \\
& $\mathrm{dH}{ }_{2} \mathrm{O}$ & $4.73 \pm 0.30^{\mathrm{b}} \mathrm{Ab}$ & $4.69 \pm 0.27^{\mathrm{ab}} \mathrm{Ab}$ & $6.53 \pm 0.27^{\mathrm{b}} \mathrm{Bb}$ & $7.60 \pm 0.61^{\mathrm{b}} \mathrm{Cb}$ \\
\hline S. Typhimurium & $\mathrm{TA}$ & $4.07 \pm 0.41^{\mathrm{a}} \mathrm{ABab}$ & $3.60 \pm 0.21^{\mathrm{a}} \mathrm{Aa}$ & $4.09 \pm 0.24^{\mathrm{a}} \mathrm{ABab}$ & $4.58 \pm 0.21^{\mathrm{a}} \mathrm{Ba}$ \\
(log CFU/g) & $\mathrm{TA}+\mathrm{GO}$ & $3.58 \pm 0.24^{\mathrm{a}} \mathrm{Aa}$ & $3.42 \pm 0.11^{\mathrm{a}} \mathrm{Aa}$ & $3.82 \pm 0.23^{\mathrm{a}} \mathrm{Aa}$ & $4.59 \pm 0.23^{\mathrm{ab}} \mathrm{Ba}$ \\
& $\mathrm{GO}$ & $4.63 \pm 0.61^{\mathrm{b}} \mathrm{Bbc}$ & $3.57 \pm 0.07^{\mathrm{a}} \mathrm{Aa}$ & $4.54 \pm 0.13^{\mathrm{ab}} \mathrm{Bb}$ & $4.92 \pm 0.26^{\mathrm{ab}} \mathrm{Ba}$ \\
& $\mathrm{MBS}$ & $4.77 \pm 0.34^{\mathrm{b}} \mathrm{Bbc}$ & $3.48 \pm 0.50^{\mathrm{a}} \mathrm{Aa}$ & $4.51 \pm 0.41^{\mathrm{a}} \mathrm{ABb}$ & $4.74 \pm 0.15^{\mathrm{ab}} \mathrm{Ba}$ \\
& $\mathrm{dH}{ }_{2} \mathrm{O}$ & $5.17 \pm 0.17^{\mathrm{b}} \mathrm{Ac}$ & $4.98 \pm 0.39^{\mathrm{b}} \mathrm{Ab}$ & $5.20 \pm 0.09^{\mathrm{a}} \mathrm{Ac}$ & $6.34 \pm 0.21^{\mathrm{a}} \mathrm{Bb}$ \\
\hline V. parahaemolyticus & $\mathrm{TA}$ & $3.48 \pm 0.01^{\mathrm{a}} \mathrm{Aa}$ & $3.59 \pm 0.08^{\mathrm{a}} \mathrm{ABa}$ & $3.95 \pm 0.21^{\mathrm{a}} \mathrm{Ba}$ & $4.40 \pm 0.24^{\mathrm{a}} \mathrm{Ca}$ \\
& $\mathrm{TA}+\mathrm{GO}$ & $3.48 \pm 0.00^{\mathrm{a}} \mathrm{Aa}$ & $3.47 \pm 0.10^{\mathrm{ab}} \mathrm{Aa}$ & $3.60 \pm 0.06^{\mathrm{a}} \mathrm{Aa}$ & $4.36 \pm 0.32^{\mathrm{a}} \mathrm{Ba}$ \\
& $\mathrm{GO}$ & $3.48 \pm 0.01^{\mathrm{a}} \mathrm{Aa}$ & $3.73 \pm 0.17^{\mathrm{ab}} \mathrm{Aab}$ & $4.06 \pm 0.67^{\mathrm{a}} \mathrm{Aa}$ & $4.52 \pm 0.68^{\mathrm{a}} \mathrm{Aab}$ \\
& $\mathrm{MBS}$ & $3.55 \pm 0.11^{\mathrm{a}} \mathrm{Aa}$ & $3.63 \pm 0.08^{\mathrm{a}} \mathrm{Aa}$ & $3.71 \pm 0.04^{\mathrm{a}} \mathrm{Aa}$ & $4.61 \pm 0.22^{\mathrm{a}} \mathrm{Bab}$ \\
& $\mathrm{dH}{ }_{2} \mathrm{O}$ & $3.87 \pm 0.22^{\mathrm{a}} \mathrm{Ab}$ & $3.99 \pm 0.14^{\mathrm{a}} \mathrm{Ab}$ & $4.59 \pm 0.46^{\mathrm{a}} \mathrm{Aa}$ & $5.55 \pm 0.46^{\mathrm{a}} \mathrm{Bb}$ \\
\hline
\end{tabular}

Note: Values were reported as means \pm S.D. of triplicate groups

Mean values in the same treatment/row with different uppercase were significantly different $(p<0.05)$

Mean values in the same day/column with different lowercase were significantly different $(p<0.05)$

Mean values within the same test bacteria with different superscript were significantly different $(p<0.05)$.

TA ; tartaric acid; TA+GO : tartaric acid + garlic oil; GO : garlic oil; MBS ; sodium metabisulfite

in $\mathrm{dH}_{2} \mathrm{O}$. Similar observation was made by Wan Norhana et al. (2009) in shrimp samples inoculated with $S$. Typhimurium and treated with bilimbing extract and tamarind juice.

Blue-green colonies (2-3 mm) on TCBS agar plates were calculated as $V$. parahaemolyticus. A reduction of $V$. parahaemolyticus counts was observed in shrimp treated with the treatments on day 0 except for shrimp dipped in $\mathrm{dH}_{2} \mathrm{O}$. The treatments were as effective as MBS in reducing $V$. parahaemolyticus counts (Table 2). V. parahaemolyticus counts continued to increase $(p<0.05)$ in all shrimp samples during the storage period. On day $10, V$. parahaemolyticus counts of shrimp treated with $\mathrm{dH}_{2} \mathrm{O}$ reached $5.55 \log \mathrm{CFU} / \mathrm{g}$. $V$. parahaemolyticus counts of shrimp treated with a mixture of TA+GO and TA decreased $(p<0.05)$ by 1.19 and $1.15 \log \mathrm{CFU} / \mathrm{g}$, respectively.

In general, $\mathrm{TA}, \mathrm{TA}+\mathrm{GO}$, and $\mathrm{GO}$ treatment reduces the number of bacterial counts on shrimp immediately after treatment compared to the untreated shrimp. Most organic acids elicit antibacterial activity by reducing environmental and cellular pH (Carpenter \& Broadbent, 2009). Due to the neutral $\mathrm{pH}$ of the cytoplasm, the acid dissociates into anions and protons. These molecules are not able to diffuse back across the cell membrane and hence accumulate in the cytoplasm.
Table 3 Changes in $\mathrm{pH}$ of shrimp dipped in tartaric acid (TA), garlic oil (GO), mixture of TA and GO, sodium metabisulfite (MBS) and sterile distilled water $\left(\mathrm{dH}_{2} \mathrm{O}\right)$ stored at $4^{\circ} \mathrm{C}$ for 10 days.

\begin{tabular}{llccc}
\hline Treatments & \multicolumn{4}{c}{ Storage period (days) } \\
\cline { 2 - 5 } & \multicolumn{1}{c}{0} & \multicolumn{4}{c}{7} & 10 \\
\hline $\mathrm{TA}$ & $6.69 \pm 0.13 \mathrm{Aab}$ & $7.40 \pm 0.22 \mathrm{Ba}$ & $7.87 \pm 0.06 \mathrm{Cab}$ & $7.94 \pm 0.09 \mathrm{Ca}$ \\
$\mathrm{TA}+\mathrm{GO}$ & $6.64 \pm 0.11 \mathrm{Aa}$ & $7.36 \pm 0.24 \mathrm{Ba}$ & $7.92 \pm 0.08 \mathrm{Cb}$ & $7.90 \pm 0.08 \mathrm{Ca}$ \\
$\mathrm{GO}$ & $6.88 \pm 0.08 \mathrm{Ab}$ & $7.47 \pm 0.24 \mathrm{Ba}$ & $7.96 \pm 0.07 \mathrm{Cb}$ & $8.03 \pm 0.09 \mathrm{Ca}$ \\
$\mathrm{MBS}$ & $6.80 \pm 0.20 \mathrm{Aab}$ & $7.44 \pm 0.10 \mathrm{Ba}$ & $7.79 \pm 0.05 \mathrm{Ca}$ & $7.90 \pm 0.09 \mathrm{Ca}$ \\
$\mathrm{dH}_{2} \mathrm{O}$ & $6.76 \pm 0.14 \mathrm{Aab}$ & $7.26 \pm 0.13 \mathrm{Ba}$ & $7.90 \pm 0.08 \mathrm{Cab}$ & $8.03 \pm 0.07 \mathrm{Ca}$ \\
\hline
\end{tabular}

Note: Values were reported as means \pm S.D. of triplicate groups

Mean values in the same treatment/row with different uppercase were significantly different $(p<0.05)$

Mean values in the same day/column with different lowercase were significantly different $(p<0.05)$

TA ; tartaric acid; TA+GO : tartaric acid + garlic oil; GO : garlic oil; MBS ; sodium metabisulfite 
Table 4 Changes in TBARS of shrimp dipped in tartaric acid (TA), garlic oil (GO), mixture of TA and GO, sodium metabisulfite (MBS) and sterile distilled water $\left(\mathrm{dH}_{2} \mathrm{O}\right)$ stored at $4^{\circ} \mathrm{C}$ for 10 days

\begin{tabular}{lcccc}
\hline Treatments & \multicolumn{4}{c}{ Storage period (days) $(\mathrm{mg}$ malonaldehy e $/ \mathrm{kg})$} \\
\cline { 2 - 5 } & 0 & 3 & 7 & 10 \\
\hline $\mathrm{TA}$ & $1.14 \pm 1.11 \mathrm{Aa}$ & $0.98 \pm 0.78 \mathrm{Aa}$ & $1.45 \pm 0.23 \mathrm{Aa}$ & $2.08 \pm 0.63 \mathrm{Aa}$ \\
$\mathrm{TA}+\mathrm{GO}$ & $0.70 \pm 0.39 \mathrm{Aa}$ & $0.90 \pm 0.09 \mathrm{Aa}$ & $1.39 \pm 0.43 \mathrm{ABa}$ & $2.00 \pm 0.60 \mathrm{Ba}$ \\
$\mathrm{GO}$ & $0.97 \pm 0.33 \mathrm{Aa}$ & $0.99 \pm 0.36 \mathrm{Aa}$ & $1.56 \pm 0.35 \mathrm{ABa}$ & $2.38 \pm 0.57 \mathrm{Ba}$ \\
$\mathrm{MBS}$ & $0.96 \pm 0.42 \mathrm{Aa}$ & $1.04 \pm 0.16 \mathrm{Aa}$ & $1.36 \pm 0.19 \mathrm{Aa}$ & $1.83 \pm 0.64 \mathrm{Aa}$ \\
$\mathrm{dH}_{2} \mathrm{O}$ & $1.05 \pm 0.68 \mathrm{Aa}$ & $1.36 \pm 0.25 \mathrm{Aa}$ & $1.86 \pm 0.22 \mathrm{ABa}$ & $2.66 \pm 0.44 \mathrm{Ba}$ \\
\hline
\end{tabular}

Note: Values were reported as means \pm S.D. of triplicate groups

Mean values in the same treatment/row with different uppercase were significantly different $(p<0.05)$ Mean values in the same day/column with different lowercase were significantly different $(p<0.05)$. TA : tartaric acid; TA+GO : tartaric acid + garlic oil; GO : garlic oil; MBS : sodium metabisulfite
Acidification of the cytoplasm and the energy depletion leads to physiological malfunction finally inhibiting microbial growth (Hazan, Levine, \& Abeliovich, 2004). This could also be the case for tartaric acid, where the lower $\mathrm{pH}$ of the shrimp was achieved through TA addition. The antibacterial mechanism of GO is probably due to the two GO constituents, diallyl disulfide and diallyl trisulfide that inhibit key metabolic enzymes of microorganism (Harris, Cottrell, Plummer, \& Lloyd, 2001; Benkeblia, 2004). On the other hand, the inhibitory action of metabisulfite is based essentially on various forms of interference in the enzyme structure particularly the key enzymes in living cells such as those involved in ATP and NADH production leading to cell death (Farag, 1997).

\section{pH Measurement}

The changes in $\mathrm{pH}$ of shrimp subjected to garlic oil and tartaric acid treatment during storage at $4{ }^{\circ} \mathrm{C}$ are shown in Table 3. The initial $\mathrm{pH}$ of shrimp immediately after dipping (day 0) in $\mathrm{dH}_{2} \mathrm{O}$ was 6.76 and was not different $(p<0.05)$ from $\mathrm{pH}$ of shrimp dipped in TA+GO and treated with GO. The $\mathrm{pH}$ of all shrimp samples continued to increase throughout the storage period. On day 10, pH of shrimp dipped in MBS and TA+GO was 7.90 and the lowest among the other treatments.

The $\mathrm{pH}$ continued to increase $(p<0.05)$ throughout the storage period and was in the range of $7.90-8.3$ on day 10 . The increase in $\mathrm{pH}$ could probably be due to accumulation of ammonia and amines formed during endogenous enzymatic reactions as reported in previous research. Nirmal \& Benjakul (2012) reported an increase in $\mathrm{pH}$ of white shrimp treated with green tea extract and ascorbic acid stored at $4{ }^{\circ} \mathrm{C}$. Attala (2012) also reported that the $\mathrm{pH}$ of shrimp treated with $3 \%$ citric acid and $2 \%$ sodium sulphite ranged from 6.4 6.47 and 7.59 - 7.84, respectively. However, the $\mathrm{pH}$ of shrimp at the end of the storage period in this study was higher than the $\mathrm{pH}$ of good quality shrimp, that is, 7.7 (Mehmet, Faruk, \& Hami, 2009). The treatment of shrimp with TA, GO, and MBS possibly reduced the number of bacteria by slowing down the endogenous enzymatic reactions. However, $\mathrm{pH}$ alone is not the major factor involved in antimicrobial activity of organic acids as other mechanisms could also be responsible.

\section{Thiobarbituric Acid Reactive Substances (TBARS)}

Malondialdehyde is the best-investigated lipid peroxidation product and the prototype of the so-called TBARS (Devasagayam, Boloor, \& Ramaasarma, 2003; Tsikas, 2017). TBARS are formed as a by-product of lipid oxidative damage (i.e., as degradation products of fats) and can be detected by the TBARS assay using TBA as a reagent. TBARS analysis is an important food quality index indicating fat oxidation. TBARS values should be less than $3 \mathrm{mg}$ malonaldehyde/kg in good quality products (Cadun, Kisla, \& Cakh, 2008). Changes in TBARS values in shrimp treated with garlic oil and tartaric acid during storage at $4{ }^{\circ} \mathrm{C}$ are shown in Table 4. Generally, shrimp treated with TA or GO or in combination was in good quality and not rancid. On day 0 , TBARS values of shrimp treated with TA+GO were the lowest. TBARS values increased in shrimp treated with $\mathrm{TA}+\mathrm{GO}, \mathrm{GO}$ and $\mathrm{dH}_{2} \mathrm{O}$ as storage progressed. On day 10, TBARS values for shrimp treated with MBS $(1.83 \pm 0.64 \mathrm{MDA} / \mathrm{kg})$ were the lowest followed by TA+GO $(2.00 \pm 0.60 \mathrm{MDA} / \mathrm{kg})$ and TA $(2.08 \pm 0.63 \mathrm{MDA} / \mathrm{kg})$ while shrimp treated with $\mathrm{dH}_{2} \mathrm{O}$ had the highest values $(2.66 \pm 0.44 \mathrm{MDA} /$ $\mathrm{kg})$. However, TBARS values recorded for both treated and untreated shrimp were not significantly $(p>0.05)$ different. The TBARS values recorded in this study is in agreement with Ainaz (2019) and Fang, Sun, Huang, \& Yuan (2013) in Metapenaeus affinis and Pacific white shrimp (Litopenaeus vannamei) stored at chilled temperature, respectively. The increase of TBARS through time was in agreement with the microorganism activity during storage, resulting in partial dehydration of shrimp tissue containing highly polyunsaturated fatty acid. The damage of tissues and interacting lipids with 
air oxygen may induce lipid oxidation. A similar observation has been described by Kilincceker, Dogan, and Kucukoner (2009) and Fang et al. (2013).

The treatments with TA and GO (alone and in combination) have no significant $(p<0.05)$ effect on lipid oxidation of fresh shrimp in this study. Perhaps, storage for just 10 days was not long enough for rancidity to set. In this study, TBARS values on day 10 for treated shrimp were still below the recommended level of $7.0 \mathrm{mg}$ malonaldehyde/ $\mathrm{kg}$ for good quality shrimp as proposed by Cadun et al. (2008).

\section{Conclusion}

Dipping of fresh shrimp in GO and TA influenced TPC, PBC, L. monocytogenes, S. Typhimurium, $V$. parahaemolyticus and TBARS values during the storage at $4^{\circ} \mathrm{C}$. Compared to sodium metabisulfite, the mixture of $\mathrm{TA}+\mathrm{GO}$ was more effective in inhibiting the growth of $S$. Typhimurium and V. parahaemolyticus. In terms of rancidity, the changes in TBARS values of shrimp treated with tartaric acid and sodium metabisulfite remained low during storage period. TBARS values of treatment and control shrimp did not differ from each other throughout the storage period except on day 0 . A mixture of $\mathrm{TA}+\mathrm{GO}$ solutions can be used to reduce the growth of $S$. Typhimurium and V. parahaemolyticus in shrimp during storage, which could reduce the incidence of foodborne pathogens and diseases.

\section{Acknowledgment}

We would like to thank the Malaysian Ministry of Science and Technology (MOSTI) for the funds allocated for this study [Project I.D. 02-03-06-SF0009]. This manuscript is part of second author Master Thesis at Universiti Sains Malaysia in 2016.

\section{References}

Ainaz K. (2019). Freshness assessment of shrimp Metapenaeus affinis by quality index method and estimation of its shelf life. International Journal of Food. Properties, 22(1), 309-319. doi: 10.1080/ 10942912.2019.1580719

Amagliani, G, Brandi, G., \& Schiavano, G F. (2012). Incidence and role of Salmonella in seafood safety. Food Research International, 45, 780-788. doi: 10.1016/ j.foodres.2011.06.022

Attala O. A. (2012). Impact of using organic acids and sodium sulfite on the quality of unpeeled shrimp. World Journal of Fish and Marine, 14: 284-289. doi: 10.5829/ idosi. wjfms.2012.04.03.6356

Bahurmiz, O.M., Ahmad, R., Ismail, N., Adzitey, F. \& Sulaiman, S.F. (2016). Antimicrobial activity of various plant extracts on Pseudomonas species associated with spoilage of chilled fish. Turkish Journal of Agriculture
- Food Science and Technology, 4, 1017-1023. doi: 10.24925/turjaf.v4i11.1017-1023.668

Benkeblia, N. (2004). Antimicrobial activity of essential oil extracts of various onions (Allium cepa) and garlic (Allium sativum). Lwt - Food Science and Technology, 37, 263-268. doi: 10.1016/j.lwt.2003.09.001

Cadun, A., Kisla, D. \& Cakh, S. (2008). Marination of deepwater pink shrimp with rosemary extract and determination of its shelf-life. Food Chem, 109, 8187. doi: 10.1016/j.foodchem.2007.12.021.

Carpenter, C.E., \& Broadbent, J.R. (2009). External concentration of organic acid anions and $\mathrm{pH}$ : key independent variables for studying how organic acids inhibit growth of bacteria in mildly acidic foods. Journal of Food Science, 74(1): R12-5. doi: 10.1111/ j.1750-3841.2008.00994.x. PMID: 19200113.

Consumer Reports. (2015). How Safe Is Your Shrimp? Consumer Reports' guide to choosing the healthiest, tastiest, and most responsibly sourced shrimp. https:/ /www.consumerreports.org/cro/magazine/2015/06/ shrimp-safety/index.htm. Date of accessed 4 November 2020.

Devasagayam, T. P, A., Boloor, K. K. \& Ramaasarma, T. (2003). Methods for estimating lipid peroxidation: An analysis of merits and demerits. Indian Journal of Biochemistry and Biophysics, 40, 300-308.

Fang, X. B., Sun, H. Y., Huang, B. Y., \& Yuan, G. F. (2013). Effect of pomegranate peel extract on the melanosis of Pacific white shrimp (Litopenaeus vannamei) during iced storage. Journal of Food, Agriculture and Environment, 11(1), 105-109. doi: 10.1234/4.2013.3786

Farag, M.K. (1997). Inactivation of common species of food poisoning bacteria by addition of some chemical preservatives. Emir. Journal of Agricultural Science, $9,62-80$

FAO. (2016). The State of world fisheries and aquaculture: Contributing to food security and nutrition for all. Rome: 2016. p. 200.

Gram, L. \& Huss, H.H. (1996). Microbiological spoilage of fish and fish products. International Journal of Food Microbiology, 33, 121-137. doi: 10.1016/0168-1605 (96)01134-8

Harris, J. C., Cottrell, S. L., Plummer, S. \& Lloyd, D. (2001). Antimicrobial properties of Allium sativum (garlic). Applied Microbiology and Biotechnology, 57, 282286.

Hazan, R., Levine, A., \& Abeliovich, H. (2004). Benzoic acid, a weak organic acid food preservative, exerts specific effects on intracellular membrane trafficking pathways in Saccharomyces cerevisiae. Applied and Environmental Microbiology, 70(8): 4449-4457.

ICMSF. (1986). Microorganisms in Foods 2. Sampling for microbiological analysis: Principles and specific applications. 2nd ed. Blackwell Scientific Publishing.

Imran, A., Chawalit, J. \& Somrote, K. (2013). Characterization of quality degradation during chilled shrimp (Litopenaeus vannamei) supply chain. International Food Research Journal, 20, 1833 -1842.

Karatas, F., Karatape, M. \& Baysar, A. (2002). Determination of free malondialdehyde in human serum by high-performance liquid chromatography. 
Analytical Biochemistry, 311, 76-79. doi:10.1016/S00032697(02)00387-1.

Kilincceker, O., Dogan, I. S. \& Kucukoner, E. (2009). Effect of edible coatings on the quality of frozen fish fillets. LWT - Food Science and Technology, 42, 868-873. doi: 10.1016/j.lwt.2008.11.003.

National Advisory Committee on Microbiological Criteria for Foods (NACMCF). (2008). Response to the questions posed by the Food and Drug Administration and the National Marine Fisheries Service regarding determination of cooking parameters for safe seafood for consumers. Journal of Food Protection, 71(6), 1287 -1308. doi: 10.4315/0362-028X-71.6.1287

Nirmal, N.P. \& Benjakul, S. (2012). Effect of green tea extract in combination with ascorbic acid on the retardation of melanosis and quality changes of Pacific white shrimp during iced storage. Food and Bioprocess Technology, 5, 2941- 2951. doi:10.1007/s11947-0100483-5

Maneesin, P., Chinnasri, N., Vongsawasdi, P. \& Wangchanachai, G. (2013). Effect of garlic oil and modified atmosphere packaging on the quality of chilled shrimp. In: IAPRI Symposium 2013. Packaging Technology and Science. John Wiley \& Sons Ltd.

Mehmet, B., Faruk, B, \& Hami, A. (2009). Preservation and shelf - life extension of shrimp and clams by high hydrostatic pressure.International Journal of Food Science \& Technology, 44, 1495-1502.

Over, K.F., Hettiarachchy, N., Johnson, M.G. \& Davis, B. (2009). Effect of organic acids and plant extracts on Esherichia coli $\mathrm{O} 157: \mathrm{H7}$, Listeria monocytogenes, and Salmonella Typhimurium in broth culture mode; and chicken meat system. Journal of Food Science, 74,515521. doi:10.1111/j.1750-3841.2009.01375.x

Rohani, S. M. R., Moradi, M., Mehdizadeh, T., SaeiDehkordi, S. S. \& Griffiths, M. W. (2011). The effect of nisin and garlic (Allium sativum L.) essential oil separately and in combination on the growth of Listeria monocytogenes LWT - Food Science and Technology, 44(10): 2260-2265. doi: 10.1016/j.lwt.2011.07.020.

Salem, A.M., \& Amin, R.A. (2012). Evaluation of some organic acids as potential decontaminants of Vibrio parahaemolyticus in fresh shrimp. World Journal of Dairy \& Food Sciences, 7, 41-48. doi: 10.5829/idosi. wjdfs.2012.7.1.62151

Takeungwongtrakul, S. \& Benjakul, S. (2014). Oxidative stability of lipids from hepatopancreas of Pacific white shrimp (Litopenaeus vannamei) as affected by essential oils incorporation. European Journal of Lipid Science and Technology, 116(8): 987-995.doi: 10.1002/ejlt. 201400042

USFDA, (2008). Report to Congress. Food and Drug Administration Amendments Act of 2007. Public Law 110-85 Section 1006 - Enhanced Aquaculture and Seafood Inspection. https://www.fda.gov/food/ seafood-guidance-documents-regulatory-information/ enhanced-aquaculture-and-seafood-in spectionreport-congress. Date of accessed 4 November 2020.

Thepnuan, R., Benjakul, S. \& Visessanguan, W. (2008). Effect of pyrophosphate and 4 - hexylresorcinol pretreatment on quality of refrigerated white shrimp (Litopenaeus vannamei) kept under modified atmosphere packaging. Journal of Food Science, 73, 124-133. doi: 10.1111/j.1750-3841.2008.00674.x

Tsikas, D. (2017). Assessment of lipid peroxidation by measuring malondialdehyde (MDA) and relatives in biological samples: Analytical and biological challenges, Analytical Biochemistry, 524, 13-30. doi: 10.1016/j.ab.2016.10.021

Wan Norhana, M.N., Nannthini, S., Huda, N. \& Adzitey, F. (2018). The effects of essential oils and organic acids on microbiological and physicochemical qualities of whole shrimp stored at $4^{\circ} \mathrm{C}$. Current Nutrition \& Food Science, 6(2), 273-283. doi: 10.12944/CRNFSJ.6.2.03

Wan Norhana, M.N., Poole, S.E., Deeth, H.C. \& Dykes, G.A. (2012). Effects of nisin, EDTA and salts of organic acids on Listeria monocytogenes, Salmonella and native microflora on fresh vacuum packaged shrimp stored at $4^{\circ} \mathrm{C}$. Journal Food Microbiology, 31,43-50. doi: 10.1016/j.fm.2012.01.007.

Wan Norhana, M.N., Poole, S.E., Deeth, H.C. \& Dykes, G.A. (2010). Prevalence, persistence and control of Salmonella and Listeria in shrimp and shrimp products: A review. Food Control, 21, 343-361. doi:10.1016/ j.foodcont.2009.06.020

Wan Norhana, M.N., Azman, M.N., Poole, S.E., Deeth, H.C. \& Dykes, G.A. (2009). Effects of bilimbi (Averrhoa bilimbi L.) and tamarind (Tamarindus indica L.) juice on Listeria monocytogenes Scott A and Salmonella Typhimurium ATCC14028 and the sensory properties of raw shrimp. International Journal of Food Microbiology, 136: 88-94. doi: 10.1016/j.ijfoodmicro. 2009.09.011

Zarei, M., Borujeni, M.P., Jamnejad, A. \& Khezrzadeh, M. (2012). Seasonal prevalence of Vibrio species in retail shrimp with an emphasis on Vibrio parahaemolyticus. Food Control, 25, 107-109. doi: 10.1016/j.foodcont. 2011.10.024 